\title{
Oil price volatility, macro-finance interactions and the role of monetary chocks
}

\author{
Hammami Algia*, GmidéneSamia \\ Faculty of Economic Sciences and Management of Sfax Rte \'s airport km 4 BP 1088.3018 Sfax \\ *Corresponding author E-mail:hammamialgia@yahoo.fr
}

\begin{abstract}
This paper deals the impact of major external (monetary, financial, Oil supply, aggregate demand) shocks on the real oil price. For this reason, we use the structural VAR methodology (SVAR) on the basis of which we define five structural shock estimate SVAR models to determine the relationship between these five shocks.

This paper presents the dynamic effects of these shocks on the real oil price and estimates the estimated contribution of these shocks to real oil price during the M11995- M2 2013 periods. Therefore, the objective of this paper is to identify the structural shocks underlying the real oil price.

The results show that financial and monetary chocks are two key determinants of oil prices. The results indicate that the period of financial stress has contributed to the downturn of the economy by boosting the cost of credit and making businesses, households, and financial institutions highly cautious, and consequently to rise of oil price.
\end{abstract}

Keywords: Oil Supply Shocks; Financial Chocks; Oil-Specific Demand Shock; SVAR Models.

\section{Introduction}

The recent volatility of crude oil prices has attracted attention to the key causes of this volatility. An interesting feature investigates that this surge was accompanied by not only a relatively high world economic growth and an increase in oil supply and demand on oil price, but also by a generally low level of short-term interest rate and financial chocks. Moreover, an inverse relationship between oil prices and real interest rates is also justified by economic theory, as argued by working (1949) who states that is a lower real interest rate leads to increased hoarding of oil, thereby leading to an increase in its price. Therefore, it is intriguing to conduct an empirical assessment of whether these factors actually influence oil prices.

The identification strategy relies on a simple assumption based on the fact that oil prices have contemporaneous effects on financial markets but not vice versa. This assumption is in line with the existing literature. For example, Hakkio and Keeton, 2009 and Davig and Hakkio, 2010 adopted this framework to demonstrate that an increase in the financial stress will be associated with higher funding costs and greater economic uncertainty, which leads to the decline of the real economic activity. Moreover, an increased financial stress will make financial investors more risk averse. As a result investment in asset markets will be discouraged, which causes the fall of asset prices, including the oil ones. To the best of our knowledge, this study is the first to use the difference impact between monetary financial and macroeconomic chocks in oil price. The contribution of this research is the public introduction and assessment of a financial stress index, which of a broad range of financial market phenomena formulated and used by the Federal Reserve Board staff during the crisis on the fly, as it were to analyze the financial conditions and their macroeconomic consequences.

In this paper, we identify the macro-finance interfaces that underlie oil price changes between 1995 and 2013 by estimating a SVAR model. The shocks to be identified to include monetary, aggregate demand, oil supply, oil-specific demand and financial shocks. This paper is organized as follows: We present the introduction in section 1 . In section 2 , we review the related literature. Section 3 describes the data and methodology. Section 4 presents the results and interpretations. Section 5 concludes.

\section{Literature review}

As put forth by several authors, the impact of oil price shocks crucially depends on the source of oil price fluctuation. Therefore, it is important to understand the causes and consequences of oil price shocks ever since the 1970. Oil price shocks have been blamed for the U.S. recessions and for higher inflation, slow down productivity in the 1970, and stagflation (a term coined to refer to the unprecedented coincidence of inflation and economic stagnation during the 1970). These chocks have also been held responsible for changes in the monetary policy, for far-reaching labor market adjustments, and for changes in energy technologies. While the interest in oil price shocks waned in the 1990, the fluctuations in the real oil price since 2003 have led to a resurgence of research on oil markets.

The sustained increase in oil prices since 1999 is mainly caused by global aggregate demand and, in particular, by buoyant demand stemming from emerging markets, defying the predictions of standard macroeconomic models that treated the rise in oil prices as an exogenous shock (Hamilton, 2008). According to (Kilian, 2009; Bodenstein and Guerrieri 2011), changes in oil price may be 
driven by different oil-market specific demand or supply shocks or by global economic developments and may therefore have different implications on the domestic and global macroeconomic variables. In the same context, Sascha Buetzer, Maurizio Michael Habib and Livio Stracca (2012) a found a relationship between oil shocks and the real and nominal exchanges' rates for 44 advanced and emerging countries. They identified three structural shocks (oil supply, global demand, and oil specific demand), which raise the real oil price, and analyzed their effect on the individual exchange rates.

Numerous studies have investigated the relationship between real oil prices and global economic activity, (Gately and Huntington, 2002; Griffin and Schulman, 2005; Krichene, 2006, Askari and Krichene, 2008; He et al., 2010). Kilian (2008) used a newly developed measure of global economic activity (the Kilian Economic Index), and proposed a structural decomposition of the real price of crude oil into three components: supply shocks, shocks to the global demand for all industrial commodities, and demand shocks that are specific to the crude oil market. The results show that an aggregate demand expansion shock in the global commodity markets, which is caused by a global economic activity, results in a large, persistent and statistically significant increase in the real oil price. Kalian's paper quantifies the magnitude and timing of the global economic shock and its dynamic effects on the real oil price. Yanan He, Shouyang Wang and Kin Keung Lai (2010) investigate the co integrating relationship between crude oil prices and the global economic activity (kilian index). These results based on the ECM show that the adjustment implied by a permanent change in the Kilian economic index is a relatively drawn out process.

Chung-Rou Fang and Shih-Yi You (2014) examined on the relationship between oil price shocks and the large Newly Industrialized Economies (NIEs). They revised the procedure of Kilian and Park (2009) and investigated how explicit structural shocks that characterize the endogenous character of changes in oil prices affect three large NIEs' stock-market returns, in order to fill this gap.

In contrast, only a few studies have explored the relation between the real interest rates and real oil prices. Frankel (2006) identified a negative relationship between the two over the period 1950 1979. On the other hand, Akram (2009) found that commodity prices, particularly the oil ones, increased significantly with negative shocks on the real interest rates and the US dollar over the period 1990-2007. An inverse relationship between oil prices and real interest rates is also justified by economic theory, as argued by working (1949), in that a lower real interest rate leads to increased hoarding of oil, thereby leading to an increase in its price. Go Tamakoshia and Shigeyuki Hamori 2012 examined the relationship between real oil prices, global economic activity, real value of the US dollar, and real interest rates during the period 1988:1 to 2011:12. They employed the Gregory and Hansen (1996) co integration test with structural breaks to investigate the long-run equilibrium and analyze the short-term Granger causality as well. Their results indicate that real oil prices are co integrated with the three factors mentioned above and affected positively by the real economic activity and negatively by the real interest rates and the real value of the US dollar. They also found a significant short-run causality from the real economic activity to real oil prices, but no significant causality from the real interest rate and real value of US dollar to real oil price is detected.

Recent literature

Recent paper has documented that these oil supply shock measures alone do not explain the bulk of oil price fluctuations (Kilian 2008a). Although it is evident from informal evidence that demand shocks play an important role in the crude oil market, the problem of quantifying these demand shocks has, thus far, proven elusive. Therefore, a new proof for the financialization of commodity markets, which a phenomenon characterized by a high degree of price correlation among a broad set of commodities as well as between commodities and financial assets, is presumably due to the greater participation of financial investors in commodity markets (Henderson et al., 2012, Nissanke, 2012, Singelton, 2012, Tang and Xiong, 2012, Buyuksahin and Robe, 2012, Morana, 2013 and Basak and Pavlova, 2013).One of the consequences of the financialization process is that commodity prices, such as those of oil, are caused not only by their supply and demand but also by the financial market conditions that affect financial investment. In this context, Wang Chen, Shigeyuki Hamori and TakujiKinkyo 2014 identified an exogenous shock arising from changes in financial market conditions and examined the consequent macroeconomic impacts of oil price changes. They found that a financial shock is a key determinant of oil prices, and its macroeconomic impact is as important as the impact of other underlying shocks. This result indicates that policymakers must explicitly consider changes in financial market conditions when analyzing the impacts of oil shocks.

Jonas Dovern and Björn van Roye June 2013 analyzed the international transmission of financial stress and its effects on the economic activity. They constructed country-specific monthly financial stress indexes (FSI) using dynamic factor models from 1970 to 2012 for 20 countries. Their results show that there is a strong co-movement of the FSI during financial crises and that the FSI of financially open countries are relatively more correlated with FSI in other countries. Subsequently, these authors investigated the international transmission of financial stress and its impact on economic activity in a Global VAR (GVAR) model. They showed that financial stress is quickly transmitted internationally and has a lagged but persistent negative effect on economic activity, and that economic slowdowns induce only limited financial stress.

\section{Data and methodology}

\subsection{Data description}

This paper uses monthly data and spans the period between January 1995 to December 2013. The variables analyzed in this paper include rapt (global crude oil production, global real economic activity, real oil prices, the KCFSI and short-term interest rate. rate.

Monetary shocks are measured by short terms interest rates, whereas global crude oil production is measured by using the total world crude oil production provided by the Oil and Gas Journal. Global real economic activity is measured by using the index developed by Kilian (2009). This index is constructed by using single-voyage freight rates for bulk dry commodity cargoes. It is then deflated by the US consumer price Index and linearly de-trended in order to remove the effects of technological advances in shipbuilding and other long-term trends in demand for sea transport. Real oil price is measured by using the US West Texas Intermediate price deflated by the US producer price index. The data were collected from the IMF's International Financial Statistics. Finally, we use the KCFSI as a proxy for global financial market conditions.

A VAR model is estimated by using the log-difference for all the variables divided by 100 . The sample period runs from January 1995 to December 2013. Which is line the approach taken by Kilian (2009)? 

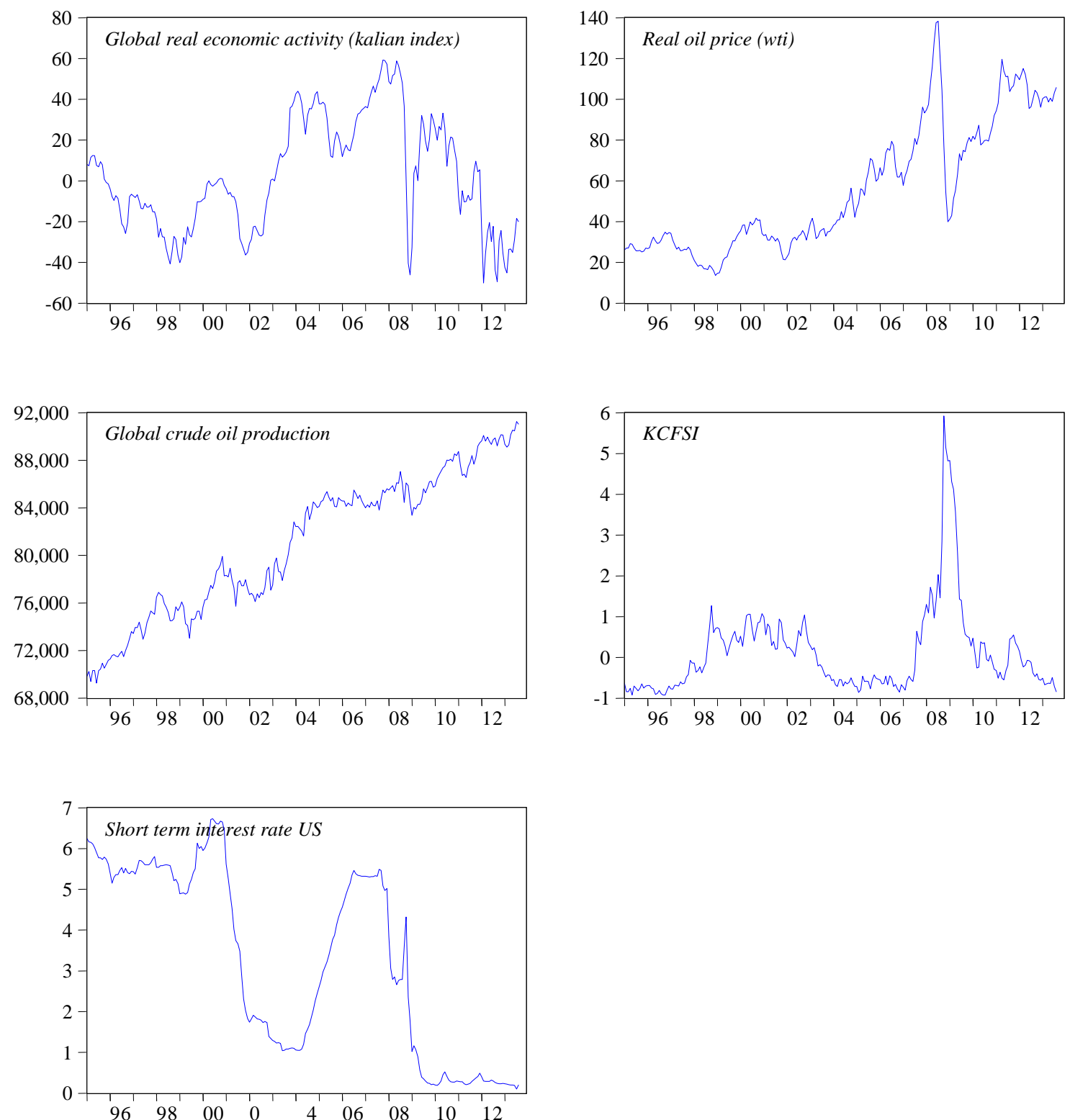

Fig1: The graphs of the dynamics for the five variables are represented. The Similar behavior of global crude oil production, global real economic activity, real oil price, kcfsi index and short-terms interest rate American.

Note: the 5-year US interest rates are extracted from the database of the U.S.Board of Governors of the Federal Reserve System. WTI spot price, Global reel economic activity in the United States, Global crude oil production are provided by the Energy Information Administration (EIA). The data of KCFSI index are available on a monthly basis from the early 1990s until recently and can be downloaded at http://www.kc.frb.org/research/indicatorsdata/kcfsi/.

\subsection{The structural VAR model}

A standard VAR representation is used to generate the results, which are summarized using impulse responses and forecast error variance decompositions. In this paper, we use the macro- finance shocks that underlie oil price volatility by estimating a VAR model.

The macro-finance shocks to be identified include oil (aggregate demand, supply, specific demand) shocks and (financial, monetary) shocks. A VAR model is estimated by using the logdifference of COP and ROP and the levels of the KCFSI, REA and the U S short term interest divided by 100 .

This model SVAR is represented as follow:

$$
\mathrm{A}_{0} \mathrm{Y}_{\mathrm{t}}=\alpha+\sum_{\mathrm{i}=1}^{\mathrm{p}} \mathrm{A}_{\mathrm{i}} \mathrm{Y}_{\mathrm{t}-\mathrm{i}}+\varepsilon_{\mathrm{t}}
$$

where $\mathrm{yt}$ is a $(5 \times 1)$ vector that contains macro-finance Variables global crude oil production (COP), global real economic activity
(REA), real oil prices (ROP), the KCFSI index and the U S short term interest rate, A 0 is a contemporaneous coefficient matrix, $\alpha$ denotes a vector of constant terms, and $\varepsilon \mathrm{t}$ is a vector of serially and mutually uncorrelated structural shocks.

$$
\mathrm{e}_{\mathrm{t}}=\mathrm{A}_{0}^{-1} \varepsilon_{\mathrm{t}}
$$

Where, e denotes the reduced-form errors.

Kilian and Vega 2011, show that oil prices do not respond contemporaneously to domestic macroeconomic news, which is consistent with the commonly used identifying assumption that oil price shocks are predetermined with respect to domestic macroeconomic aggregates.

Hence, the reduced-form VAR is obtained by multiplying both sides of Eq. (1) by

This has the following recursive structure: 


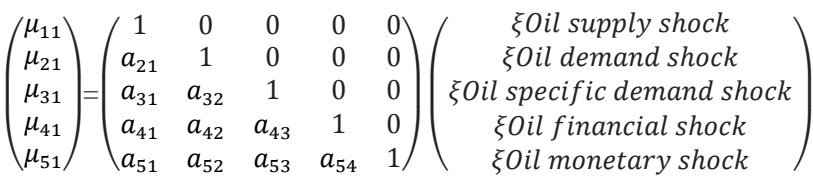

\section{Empirical results}

\section{1. Structural shocks that underlie oil price changes}

In this paper, we identify the structural shocks that underlie oil price changes by estimating a VAR model. The structural shocks to be identified include a oil supply, aggregate demand, oilspecific demand, and financial shocks. The structural representation of the VAR model is as follows: $\mathrm{Y}_{\mathrm{t}}$ is a $(5 \times 1)$ vector that contains global crude oil production (COP), global real economic activity (REA), real oil prices (ROP), KCFSI index and short terms interest rate, A 0 denotes a contemporaneous coefficient matrix, $\alpha$ is a vector of constant terms, and $\varepsilon \mathrm{t}$ denotes a vector of serially and mutually uncorrelated structural shocks.

Tables 1: Description of Variables

\begin{tabular}{|c|c|}
\hline $\mathrm{COP}$ & $\begin{array}{l}\text { Oil supply shock is measured by using the total world crude oil } \\
\text { production. }\end{array}$ \\
\hline REA & $\begin{array}{l}\text { Aggregate demand shock is measured by using the index devel- } \\
\text { oped by Kilian (2009). }\end{array}$ \\
\hline & Oil-specific demand shock is measured by using the US West \\
\hline ROP & $\begin{array}{l}\text { Texas Intermediate price deflated by the US producer price } \\
\text { index. }\end{array}$ \\
\hline KCFSI & $\begin{array}{l}\text { Financial shock is measured by global financial market condi- } \\
\text { tions }\end{array}$ \\
\hline $\mathrm{MC}$ & $\begin{array}{l}\text { Monetary chocks (lower word interest rates) are measured by } \\
\text { US short terms interest rate (Fed Fund). }\end{array}$ \\
\hline
\end{tabular}

Notes: COP, REA, ROP, KCFSI and MC indicate Oil supply shock, Aggregate demand shock, Oil-specific demand shocks and Monetary chocks respectively.
Table 2: Summary Statistics for the Crude Oil Price and Each Factor during the Period Janvier 1995-December 2013.

\begin{tabular}{llllll}
\hline & COP & REA & ROP & KCFSI & CM \\
\hline Mean & 81001.53 & 2.442500 & 55.77208 & 0.109554 & 3.256205 \\
Median & 82632.95 & -0.383988 & 41.40032 & -0.200000 & 3.525000 \\
Maximum & 91252.58 & 59.25579 & 138.2602 & 5.920000 & 6.730000 \\
Minimum & 69271.63 & -50.07206 & 13.53655 & -0.920000 & 0.100000 \\
Std. Dev. & 5972.462 & 27.19558 & 31.43071 & 1.082203 & 2.286054 \\
Skewness & -0.179109 & 0.210814 & 0.647582 & 2.633925 & -0.100476 \\
Kurtosis & 1.795916 & 2.080240 & 2.165717 & 12.05135 & 1.357374 \\
Jarque-Bera & 14.72928 & 9.554786 & 22.15246 & 1023.653 & 25.56029 \\
Probability & 0.000633 & 0.008418 & 0.000015 & 0.000000 & 0.000003 \\
\hline
\end{tabular}

Notes: COP, REA, ROP, KCFSI and MC indicate Oil supply shock, Aggregate demand shock, Oil-specific demand shocks and Monetary chocks respectively. The figures stand for test statistics of the Skewness, Kurtosis, and Jarque-Bera.

The results of the Jarque-Bera test indicate that most variables do not follow a normal distribution. In general, the standard deviation reflects the volatility of variables. The standard deviation of most variables has no major changes in the scale of any long-time throughout the period. As the table (2) shows, the maximum value of the financial constraint is observed for the United States $(5,92)$ this positive value indicates that financial stress is above the longterm average, which would discourage investment in asset markets, including oil markets. This value reflects the major episodes of financial distress and the financial turmoil following the collapse of Lehman Brothers, as shown by the peak in mid-2008.

\subsection{Impulse response to structural shocks}

To illustrate the relative importance of the identified structural shocks as sources of oil price changes, the cumulative impulse responses of ROP and other variables to a one-standard deviation shock are shown below: 


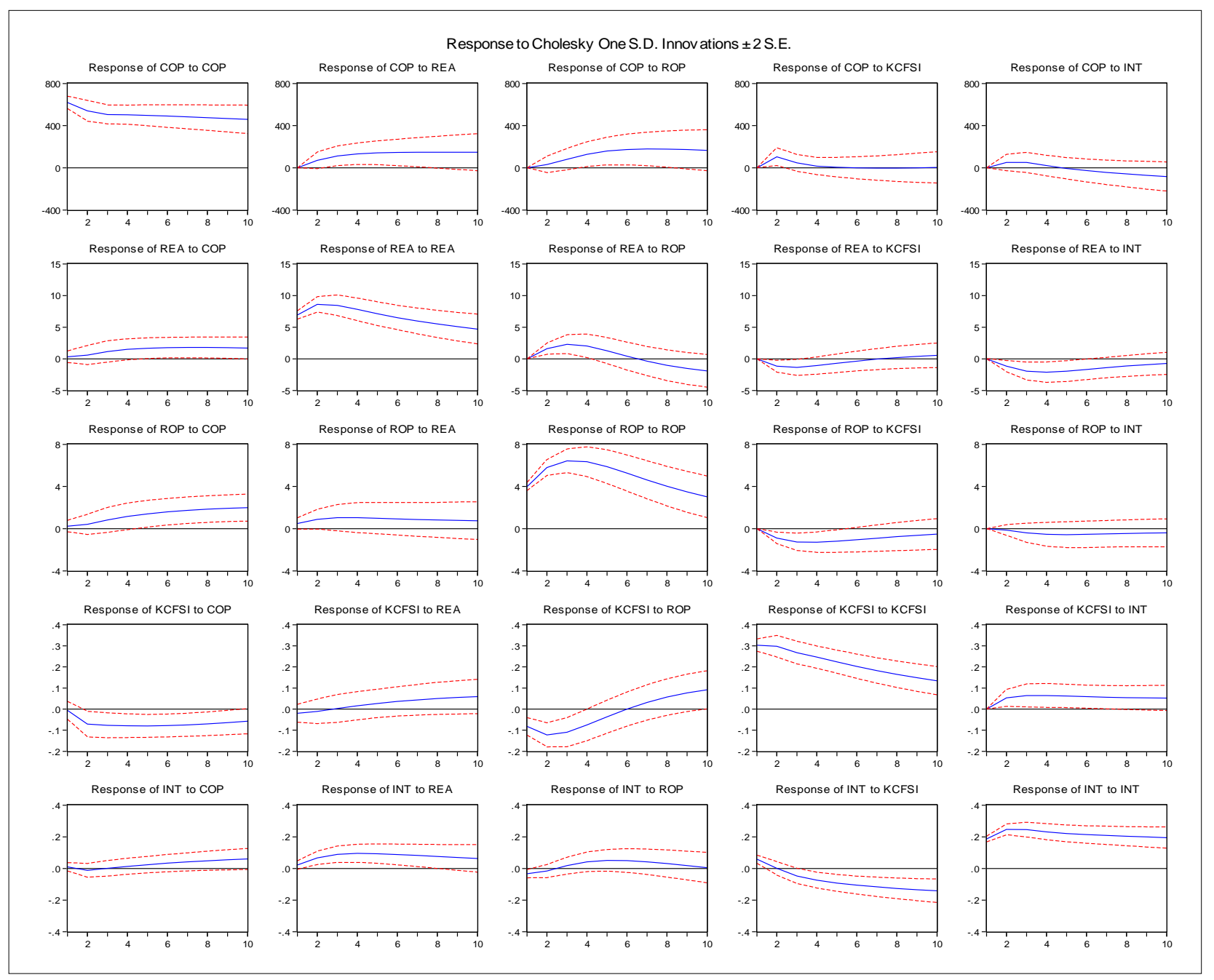

Figure 2: Response of WTI crude oil price to different shocks.

Note: Cumulated responses to a one SD. shock with-standard error confidence bands. The dotted lines represent two-standard error hands.

The dotted lines represent two-standard error bands. The variable being shocked is the same in each column, and the rows indicate the variables responding to the shock. For example, the first column has the impulse response of each variable in the system to innovation in the US short terms interest rate. The dashed lines correspond to more or less two standard errors around the impulse responses. Our primary interest is in the response of the KCFSI index to an innovation in the oil price. This can be found in the third row, third column.

Other impulse responses move as expected as well. The first column of the third row shows that innovation in the US short term interest rate decreases oil price. This result shows that the oil price has responded inversely to unexpected movements in the US short- term real interest rates since at least 1995. This is much consistent with the research work of See Hamilton (2009) on this point. This may have important implications for the impact of the US monetary policy on oil prices as well (Krichene, 2006) Frankel (2006) and others state that a lower federal funds rate can lead to higher oil prices. This assumes that a lower federal funds rate leads to a fall in the corresponding short-term rates, as is widely believed.

The inverse relationship between the US short term interest rate and oil price is explained by the portfolio reallocation and the increased financialization of commodity markets in general, and the oil market in particular ( Tang and Xiong, 2010 ). Facing low (and falling) global real interest rates, investors have moved out of other assets into commodities, particularly oil futures. Ostensibly, the increased flows into the oil market have resulted in higher prices, thereby strengthening the inverse relationship. Moreover, an inverse relationship between oil prices and real interest rates is also justified by the economic theory, as argued by working (1949), who states that is, a lower real interest rate leads to increased hoarding of oil, thereby leading to an increase in its price.

The impulse response of ROP to kanas city financial stress is of particular interest herein. The result Real oil price (wti)

Global crude oil production KCFSI Short term interest rate US indicate that oil price declines with a positive financial shock, which implies an increase in financial stress. Such an unexpected worsening of financial conditions causes a statistically significant decline in the ROP. We also find that a positive financial shock depresses real economic activity. The findings presented in this section indicate that a financial shock is an important determinant of oil prices. This result seems to lend some support to the view that oil markets have become financial zed in the sense that oil prices are significantly driven by changes in financial market conditions that affect financial investment. This finding is similar to the results of (Hakkio and Keeton 2009, Hubrichand Tetlow2012,Mittnikand Semmler2013,Cevikand al., 2012 and van Roye2014), who found for the US that an increase in financial stress significantly reduces economic activity. In the same context, (Hakkio and Keeton, 2009, Davig and Hakkio, 2010 and Wang Chen, Shigeyuki Hamori and TakujiKinkyo (2014) indicate that an increase in financial stress can lead to a decline in the economic activity. Moreover, financial stress is associated with two kinds of uncertainty about the fundamental value of assets and uncertainty 
about the behavior of other investors. Both kinds of uncertainty lead to increased volatility in the asset prices. The increased financial stress will make financial investors more risk averse, which will discourage investment in asset markets, resulting in falling asset prices, including that of oil. The volatility may also induce households to cut back on spending, as they become more uncertain about their future wealth.

Our result predicts a negative and significant reaction of financial conditions to an unexpected monetary shock. The financial conditions react negatively and significantly to an unexpected monetary policy tightening. These contributions have typically found quite mild, and often insignificant, reactions of the financial indicators

\subsection{Factor contribution to oil price volatility}

In this section, we investigate the contribution of different structural shocks to the fluctuations of the variables in the VAR by estimating the forecast error variance decomposition. Table 3 to a monetary policy shock (Lee, 1992; Thorbecke, 1997; Patelis, 1997; Millard and Wells, 2003; Neri, 2004).Therefore, a relationship between kcfsi the index influence the US short term interest rate, which in turn influences international crude oil prices. Furthermore a reduction in interest rates influences the investors' expectations with respect to the increase of financial stress.

The surprising supply-driven oil price shocks are surprises that could be the consequence of production disruptions due to war, geopolitical tensions or damages to oil production capacity. A negative supply-driven price shock increases oil prices and lowers the economic activity in the USA, which is a net consumer of oil.

show the share of the fluctuations in the ROP and the KCFSI caused by its own shocks (the oil-specific demand shock and financial shock, respectively) compared to the shocks to the other variables.

Table 3: Forecast Error Variance Decomposition is then conducted for Up to 12 Months.

\begin{tabular}{|c|c|c|c|c|c|}
\hline \multicolumn{6}{|c|}{ Variance decomposition of Rea } \\
\hline Period & REA & Rop & Cop & KCFSI & Mc \\
\hline 1 & 100.0000 & 0.000000 & 0.000000 & 0.000000 & 0.000000 \\
\hline 3 & 84.59731 & 7.882644 & 0.340010 & 3.713853 & 3.466183 \\
\hline 6 & 83.35750 & 8.406638 & 0.495456 & 3.836328 & 3.904080 \\
\hline 9 & 83.24492 & 8.448432 & 0.511996 & 3.863784 & 3.930870 \\
\hline 12 & 83.24064 & 8.452747 & 0.511985 & 3.863797 & 3.930835 \\
\hline \multicolumn{6}{|c|}{ Variance decomposition of Rop } \\
\hline Period & Rea & Rop & Cop & KCFSI & Mc \\
\hline 3 & 2.123046 & 88.86047 & 0.338281 & 6.885020 & 1.793185 \\
\hline 6 & 2.227453 & 87.51807 & 0.373719 & 6.834382 & 3.046381 \\
\hline 9 & 2.259540 & 87.41197 & 0.373713 & 6.860805 & 3.093977 \\
\hline 12 & 2.259689 & 87.41058 & 0.373830 & 6.862255 & 3.093649 \\
\hline \multicolumn{6}{|c|}{ Variance decomposition of Cop } \\
\hline Period & Rea & Rop & Cop & KCFSI & Mc \\
\hline 1 & 0.312867 & 0.005697 & 99.68144 & 0.000000 & 0.000000 \\
\hline 3 & 2.091244 & 0.833216 & 93.89076 & 2.801956 & 0.382821 \\
\hline 9 & 2.319264 & 1.294716 & 91.90524 & 3.808114 & 0.672668 \\
\hline 12 & 2.319484 & 1.295205 & 91.90335 & 3.809302 & 0.672655 \\
\hline \multicolumn{6}{|c|}{ Variance decomposition of KCFSI } \\
\hline Period & Rea & Rop & Cop & KCFSI & Mc \\
\hline 1 & 1.788178 & 8.972669 & 0.051041 & 89.18811 & 0.000000 \\
\hline 3 & 1.642499 & 9.506939 & 1.569791 & 82.38240 & 4.898373 \\
\hline 6 & 1.780517 & 9.661114 & 1.802589 & 81.67833 & 5.077446 \\
\hline 9 & 1.781413 & 9.681413 & 1.812623 & 81.64948 & 5.075069 \\
\hline 12 & 1.782127 & 9.682358 & 1.812657 & 81.64795 & 5.074904 \\
\hline \multicolumn{6}{|c|}{ Variance decomposition of Mc } \\
\hline Period & Rea & Rop & Cop & KCFSI & Mc \\
\hline 1 & 1.024192 & 2.132984 & 0.350851 & 12.52364 & 83.96833 \\
\hline 3 & 7.091188 & 4.126791 & 1.293455 & 17.87938 & 69.60919 \\
\hline 6 & 7.206909 & 7.125279 & 1.321265 & 18.01716 & 66.32938 \\
\hline 9 & 7.188987 & 7.298124 & 1.320059 & 18.01883 & 66.17400 \\
\hline 12 & 7.189174 & 7.298072 & 1.320069 & 18.01819 & 66.17450 \\
\hline
\end{tabular}

Notes: The results are based on the forecast error decomposition over the horizon of 12 month and units are in s.

The fluctuations in the ROP and the KCFSI, caused by their own shocks (oil-specific demand shock and financial shock, respectively) are compared with the shocks to the other variables. A major share of ROP fluctuations is accounted for by its own shock (oilspecific demand shock), although the contribution of this shock declines over time. We note that the financial shock accounts for a larger share of ROP fluctuations than the aggregate demand shock after 12 months and thereafter.

The financial shock explains approximately $6.86 \%$ of the ROP fluctuations, and the aggregate demand shock accounts for just $2.25 \%$ after 12 months, while the, Monetary chocks explain approximately 3,09\%. On the other hand, the oil supply shock accounts for the lowest share of the ROP fluctuations $(0.37 \%$ after 12 months), which could be seen as an indicator of its low explanatory power.

These results are broadly similar to the findings in the impulse response analysis presented above. The fluctuations in the KCFSI are mostly caused by its own shock (financial shock) at all-time horizons. The combined contribution of the other shocks to KCFSI fluctuations accounts for approximately 12, 57 after 12 months.

Interestingly, we find that the share of KCFSI fluctuations caused by other shocks changes over time. For example, the aggregate monetary chocks $(5,07 \% \%)$ and oil- specific demand $(9,68 \% \%)$ account for a larger share of the KCFSI than other oil chocks until 12 months. The forecast error variance decomposition is then conducted for up to 12 months.

Overall, during the period between January 1995 and December 2013, the US short terms interest rate and kcfsi index were the main factors influencing contemporaneous oil price volatility.

However, the contributions of oil-specific demand shock to most factor volatility exceed $9 \%$ in the short and long run indicating that crude oil price volatility has great influence when its price is higher. As a result, oil price is the main factor influencing of the monetary and financial chocks. From Table 7, the percentage contribution of WTI reaches only $7,29 \%$ and $9,68 \%$. 
Under column (1) in the first month, $100 \%$ of the variability in oil price changes is explained by its own innovations. After 3 months, approximately $88,86 \%$ of the variability is explained by its own innovations, and at 12 months, approximately $87,41 \%$ of the variability is explained by innovations. This finding proves that oil price in the current period is closely related to the future pricing decisions. This confirms the finding of Yousefi and Wirjanto (2004). Who found that there is an absence of a unified and determined OPEC price in the international crude oil market. However, the connection between the current shocks and the future variable movements is even stronger in the index developed by Kilian (2009). At 12 months(as indicated under column 4), in the medium term period, the exchange rate variations are still mainly due to their own changes $(91.643 \%)$ while $97.318 \%$ are attributed to changes in the first month. This finding also confirms that the short-run shocks have the long-term effect on the Aggregate demand shock.

\subsection{Estimation equation}

Table 4: Regression results

\begin{tabular}{lllll}
\multicolumn{5}{c}{ Table 4: Regression results } \\
\hline Variable & Coefficient & Std.Error & t-Statistic & Prob \\
\hline COP & 0.035845 & 0.041951 & 0.854468 & 0.3938 \\
MC & 0.855613 & 0.658425 & 1.299484 & 0.1951 \\
KCFSI & -1.282509 & 0.978733 & -1.310377 & 0.1914 \\
COP & 0.004777 & 0.000265 & 18.04750 & 0.0000 \\
C & -333.8795 & 22.99455 & -14.51994 & 0.0000 \\
R-squared & 0,7585 & & & \\
Adjusted R -squared & 0,754 & & & \\
F-statistic & 171 & & & \\
Prob (F-statistic) & 0,00000 & & & \\
\hline
\end{tabular}

Notes: Standard errors in parentheses. Significance codes: $(10 \%)^{*}$, $(5 \%) * *$ and $(1 \%) * * *$

This table shows the impact of production, KFSI index, interest rate and activity on the real oil price. The results indicate that real activity, interest rate and production have a positive impact on the real oil price $0.035845,0.855613$ and 0.004777 , respectively. However, the KFSI index negatively influences the real oil price (1.282509).These results are similar to those found by Hakkio and Keeton 2009, Hubrich and Tetlow 2012, Mittnik and Semmler 2013, Cevik and all, 2012 and van Roye 2014.

This model explains 0,7585 of the real oil price. $F=171$ means that the share of the variance in the dependent variable explained by the model is 171 times greater than the proportion of the variance in the dependent variable which remains unexplained. The Adjusted R-squares which indicate our time series are nonstationary; therefore, we have all reasons to suspect spurious regression results.

\section{Conclusion and policy implications}

In this paper, we identified five types of structural shocks that cause changes in oil prices and assessed the relative importance of these shocks as the source of oil price changes.

Our result is characterized by a high degree of price correlationbetween kcfsi index and oil price, due to the greater participation of financial investors in commodity markets. It is also consistent with the findings of (Basher et al.2012 and Wang Chen, Shigeyuki Hamori and TakujiKinkyo 2014. Who showed that a rise in financial stress, measured by an increase in the TED spread, tends to depress real oil prices, real economic activity, and emerging stock market prices?

The impulse response analysis shows that a positive financial shock causes a statistically significant decline in oil prices, indicating that the financial shock is a key determinant of oil prices. Moreover, the estimated variance decomposition indicates that the financial shock has a relatively high explanatory power for oil price fluctuations.
The effects of the oil supply shock on the output and price levels in the USA are similar to those of Kilian (2009). The persistent increases in the global real economic activity and declines in the US short terms interest rate may lead to an increase of the real oil price. These results are important for both policymakers and investors who wish to conduct forecasts for future oil prices based on a solid understanding of their key drivers.

Prima facie, the KCFSI index appears to have some relation with REA and MC. However, this research question needs to be explored further to decipher, robust relationship between the KCFSI index, REA and MC.

\section{References}

[1] Akram, Q.F., 2009. Commodity prices, interest rates and the dollar $\begin{array}{llll}\text { Energy Economics } & 31, & \text { pp. } & 838 \tilde{n} 851\end{array}$ http://dx.doi.org/10.1016/j.eneco.2009.05.016

[2] Askari.H., Krichene. N., 2008. Oil price dynamics (2002-2006). En$\begin{array}{llll}\text { ergy } & \text { Economics } & 30 & \text { (2008) }\end{array}$ http://dx.doi.org/10.1016/j.eneco.2007.12.004.

[3] Bodenstein, M., Guerrieri, L., 2011. Oil efficiency, demand and prices A table of ups and downs. International Finance Discussion Papers

[4] Buetzer, S., Maurizio, M .H, Stracca.S., 2012. Global exchange rate configurations do oil shocks matter? Working papers series No 1442 / June 2012.

[5] Buetzer.S., Maurizio, M. H., Stracca.L ., 2012. Global exchange rate configurations do oil shocks matter? European Central Bank, Eurosystem.

[6] Buyuksahin,B., Robe, M.A., 2012. Speculators, Commodities and Cross-Market Linkages. Journal of International Money and Finance.

[7] C, Morana. 2013. Oil price dynamics, macro-finance interactions and the role of financial speculations Journal of Banking \& Finance, 37 (2013), pp. 206-226. http://dx.doi.org/10.1016/j.jbankfin.2012.08.027.

[8] Cevik.E.M. SelDibooglu.TuralayKenc., 2012. Measuring financial stress in Turkey. Journal of Policy Modeling 35 (2013) 370-383.

[9] Chung-Rou, F., Shih-Yi, Y., 2014. The impact of oil price shocks on the large emerging countries' stock prices: Evidence from China, India and Russia. International Review of Economics \& Finance.

[10]Davig, T., Hakkio, C., 2010. What is the effect of financial stress on economic activity? Economic.

[11]Dovern, J., Bj orn, v.R.., 2013. International transmission of financial stress: evidence from a GVAR. Kiel Economics and the Kiel Institute for the World Economy.

[12]Frankel, J., 2006. The Effect of Monetary Policy on Real Commodity Prices. Monetary Policy Review. http://dx.doi.org/10.3386/w12713.

[13] Gately, D., Hillard. G. H., 2002. The asymmetric effects on demand of increases and decreases in income. The Energy Journal, 2002 23(1), pp. 19-55. http://dx.doi.org/10.5547/ISSN0195-6574-EJ-Vol23-No1-2.

[14] Gately, D., Huntington, H., 2002. The asymmetric effects of changes in price and income on energy and oil demand. The Energy Journal 1 , 19-35. http://dx.doi.org/10.5547/issn0195-6574-ej-vol23-no1-2.

[15]Gregory, A. W., Hansen, B. E., 1996. Residual-Based Tests for Cointegration in Models with Regime Shifts. Joumal of Econometrics, Vol. 70, pp. 99-126. http://dx.doi.org/10.1016/0304-4076(69)41685-7.

[16]Griffin, J., Schulman, G., 2005. Price asymmetry in energy demand models: a proxy for energy-saving technical change. The Energy Journal 26 (2), 1-21. http://dx.doi.org/10.5547/ISSN0195-6574-EJVol26-No2-1.

[17] Hakkio, C.S., Keeton, W.R., 2009. Financial stress: what is it, how can it be measured, and why does it matter? Federal Reserve Bank of Kansas City. Economic Review (Second Quarter) 94 (2), 5-50.

[18]Hamilton. 2009. Understanding Crude Oil Prices. Energy Journal 30, no. 2: 179-206.

[19]Hamilton, J., 2008. Understanding crude oil prices. Tech. Rep. 14492 , National Bureau of Economic research.

[20]He, Y., Wang, SH., Lai, K.K., 2010. Global economic activity and crude oil prices: A cointegration analysis. Energy Economics, 32(4), 868-876. http://dx.doi.org/10.1016/j.eneco.2009.12.005.

[21]He, Yanan. Wang, Shouyan. Lai, Kin Keung. 2010. Global economic activity and crude oil prices: A cointegration analysis. Energy Economics, 32: 868-76. http://dx.doi.org/10.1016/j.eneco.2009.12.005.

[22]Henderson. B.J., Pearson N.D., Wang. L., 2012. New Evidence on the Financialization of Commodity Markets.

[23]Hossein, A., Krichene, N., 2008. Oil price dynamics (2002-2006). Energy Economics, 30:2134-2153. http://dx.doi.org/10.1016/j.eneco.2007.12.004. 
[24]Hubrich, K., Tetlow.R.J, 2012. Financial Stress and Economic Dynamics: the transmission of crises. Finance and Economics Discussion Series.

[25]Kilian, L., 2008. The Economic Effects of Energy Price Shocks. Journal of Economic Literature, 46(4): 871909.http://dx.doi.org/10.1257/jel.46.4.871.

[26]Kilian, L., Park, C., 2009. The impact of oil price shocks on the U.S. stock market. International Economic Review 50, $1267-$ 1287.http://dx.doi.org/10.1111/j.1468-2354.2009.00568.x.

[27]Kilian, L., Park, C., 2009. The impact of oil price shocks on the U.S. stock market. International Economic Review 50, 1267 1287.http://dx.doi.org/10.1111/j.1468-2354.2009.00568.x.

[28]Krichene, N., 2006, "World Crude Oil markets: Monetary Policy and the Recent Oil Shock," IMF working paper, WP/06/62.

[29] Krichene, N., 2006. Recent Dynamics of Crude Oil Prices. IMF Working Paper.

[30]Krichene, N., 2006. World crude oil markets: monetary policy and the recent oil shock. Tech. Rep. WP/06/62, International Monetary Fund.

[31]Lee, B. S., 1992. Causal Relations among Stock Returns, Interest Rates, Real Activity, and Inflation. The Journal of Finance, 47 (4), pp. 1591-1603.http://dx.doi.org/10.1111/j.1540-6261.1992.tb04673.x.

[32]Maslyuk, S., Smith, R., 2009. Cointegration between oil spot and futures prices of the same and different grades in the presence of structural change. Energy Policy 37, 1687e1693.

[33]Millard, S. P., Wells, M., 2003. The role of asset prices in transmitting monetary and other shocks. Bank of England Working Paper, no 188.

[34]Mittnik, S., W, Semmler. 2013. The real consequences of financial stress. Journal of Economic Dynamics and control, 37, 14791499.http://dx.doi.org/10.1016/j.jedc.2013.04.014.

[35] Nissanke, M., 2012. Commodity market linkages in the global financial crisis: excess volatility and development impacts. Journal of Development Studies, $48 \quad$ (2012), pp. 732 750.http://dx.doi.org/10.1080/00220388.2011.649259.

[36]Patelis, A. D., 1997 .Stock Return Predictability and the Role of Monetary Policy. Journal of Finance 52(5), 19511972.http://dx.doi.org/10.1111/j.1540-6261.1997.tb02747.x.

[37]S, Basak, A, Pavlova, 2013 .A Model of Financialization of Commodities SSRN (2013) http://ssrn.com/abstract=2201600 Stanford Graduate School of Business (2012).

[38] Singelton, K.L., 2012. Investor Flows and the 2008 Boom/Bust in Oil Prices. Working Paper.

[39]Stefano, N., 2004. Monetary Policy and Stock Prices. Bank of Italy Working paper No, 513, July 2004.

[40]Tamakoshi, G., Hamori, S., 2012. Real Oil Prices, Real Economic Activity, Real Interest Rates and the US Dollar: A Cointegration Analysis with Structural Breaks. Journal of Reviews and Global Economics.

[41]Tang, K., Xiong, W., 2012. Index investing and the financialization of commodities. Financial Analysts Journal 68, 5474http://dx.doi.org/10.2469/faj.v68.n6.5.

[42]Willem, T., 1997. On stock Market Returns and Monetary Policy. The Journal of Finance, $52 \quad$ (2), pp. 635654.http://dx.doi.org/10.1111/j.1540-6261.1997.tb04816.x.

[43] Yanan, H., Shouyang, W., Kin, K. L., 2010. Global economic activity and crude oil prices: A cointegration analysis. Energy Economics, 32, $876,2010$. 